\title{
Street children in Colombo: What brings them to and sustains them on the streets?
}

\author{
B C V Senaratna ${ }^{1}$, BVN Wijewardana ${ }^{2}$ \\ Sri Lanka Journal of Child Health, 2013; 42: 70-75
}

\begin{abstract}
Introduction: Street children are a vulnerable group and a social problem. Weaning them off the streets requires an understanding of push/pull factors related to street life.
\end{abstract}

Objectives: To describe factors associated with initiation and continuation of street life among street children in Colombo city.

Methods: A descriptive cross sectional study of mixed methods was conducted in Colombo Fort, Pettah, Slave Island and Maradana areas. Semistructured interviews (SSIs) were conducted with key informants using a semi-structured questionnaire (SSQ). Focus group discussions were conducted using a moderator's question guide with street children recruited through referral sampling. SSIs were also conducted with 25 street children, using a SSQ. All children identified through referral sampling were subsequently profiled. Data triangulation was used to validate data.

Results: Two hundred and eighty three children, aged 8-18 years, were recruited, 210 (74\%) being boys. Representation of minority ethnic groups was comparatively higher. Over $40 \%$ of children had been introduced to street life by their own family. Other common mediators included close family relatives, non-relative known contacts and peers. Common reported reasons for initiation of street life were: death / illness / imprisonment of one or both parent/s, extreme poverty, alcohol/substance abuse by fathers and being born in streets. One third of children lived in single-parent families and $42 \%$ with non-parent adults but $18 \%$ lacked an adult guardian. They had poor educational achievements and no occupational skills.

\footnotetext{
${ }^{1}$ Senior Lecturer in Community Medicine, ${ }^{2}$ Senior Lecturer in Criminology, University of Sri Jayewardenepura,
}

(Received on 13 March 2012: Accepted after revision on 15 June 2012)
Conclusions: Disadvantaged socio-economic conditions, poor family functioning and family influence have brought children to the streets.

(Key words: street children; initiation; continuation; rehabilitation; Sri Lanka)

\section{Introduction}

Street children are those who live on urban streets, partake in various activities on these streets but are not provided with rights due to children ${ }^{1}$. They come to streets habitually (either for an activity or not) and sustain their lives mostly by themselves ${ }^{2}$. UNICEF identifies two groups of street children, namely, 'children on the street' who lack an adult parent or guardian and do all the daily activities (including earning, eating, toileting, and sleeping) on the street and 'children of the street' who have some connection with guardians or habitations and earn their living on the street ${ }^{3}$. The most vulnerable group is "children on the street". While the reasons for these children to live on or of the street are multifactorial, their lifestyles are entirely shaped by the mixed communities of urban streets 5 .

There are an estimated 100 million street children globally ${ }^{6}$, nearly $20 \%$ of which are in South Asia ${ }^{1}$. The number of street children in Sri Lanka is estimated to be $15,000^{7}$. Most of these street children are concentrated in the city of Colombo ${ }^{7}$ which, being a busy commercial hub, provides space and a cultural and socio-economic environment suitable for their sustenance.

Although some children have adult guardians (who may or may not take care of them), some live all by themselves ${ }^{7,8}$. Whether they are cared for or not by the guardians, these children earn a living for themselves by begging, shifting and lifting goods and other material for merchants and their customers, selling lottery tickets, working in pavement (and other) stalls, selling vegetables, betel, fruits etc, providing miscellaneous manual labour, as well as by illicit means such as drug peddling, commercial sex work etc ${ }^{7}$. 
Due to frequent family disruptions, poor family functioning and the antisocial behaviours they witness in their environment, these children show poor socialisation ${ }^{5,7}$. They adopt a range of risk behaviours (including drug peddling, abusing alcohol and narcotic substances, child prostitution, violent behaviours and child labour) resulting from this insecure and disadvantaged environment they live in. Such risk behaviours not only endanger their health and make them victims of abuse, but also pose a threat to society, thus allowing them to be considered a social problem ${ }^{7}$.

Although several punitive and rehabilitative measures have been taken by state agencies to address the issue of street children, these have only been successful in forcing the street children into a hidden interface. It is therefore imperative to identify the factors that drive children to streets and compel them to sustain street life despite attempts to rehabilitate them. Unfortunately, such studies are scarce. This study was, therefore, conducted to describe the factors that force children to and sustain them on the streets.

\section{Method}

For the purpose of this descriptive cross sectional study, street children were defined as children living on the street most of the time regardless of whether they still maintained some contact with their families or not ${ }^{9}$. Study areas were Colombo Fort, Pettah, Slave Island, and Maradana areas of Colombo city, and data collection was carried out in three phases.

In Phase I, semi-structured interviews (SSIs) were conducted with key informants (KIs) including parents/guardians of street children, street vendors, persons working in boutiques in areas frequented by street children and social workers/researchers who had working experience regarding street children. KIs were identified through prior knowledge.

In Phase II, children were recruited through referral sampling for focus group discussions (FGDs), which were continued until no new information was forthcoming (ten FGDs, each with 8-10 children, aged 8 to less than 18 years). In addition, SSIs were conducted with 25 street children, selected to represent their variability in age, sex, ethnic group and religious group. The objectives of these FGDs and SSIs were to collect information regarding the factors associated with their initiation and continuation of street life. In Phase III, all children identified through referral sampling were profiled.

A pre-piloted, interviewer-administered, semistructured questionnaire (SSQ) was used for SSIs with KIs. A pre-piloted, moderator's question guide and an interviewer-administered SSQ were used, respectively, to conduct FGDs and SSIs with children. A pre-piloted, interviewer-administered questionnaire prepared based on the variables identified through SSIs and FGDs was used to profile children. All interviewers had prior experience in studies/programmes involving street children, and therefore were familiar to and had a good rapport with participants.

SSIs and FGDs were tape-recorded with the consent of the participants whenever possible and written notes were taken down. Tapes were transcribed and written notes expanded immediately after each SSI or FGD. Qualitative content analysis was used to analyse data. Frequency distributions were used in profiling children.

Data triangulation was used to substantiate and validate data collected in different phases of study.

Informed consent was obtained from all participants, including children. In addition, informed consent of parents/guardians was also obtained for participation of their children. Ethical approval was obtained from Ethical Review Committee of Faculty of Medical Sciences, University of Sri Jayewardenepura.

Whenever children were in need of support services from health, social services, or any other sector, such children were referred to relevant sector/s.

\section{Results}

KIs included 6 parents/guardians, 6 street vendors, 5 persons working in boutiques and 3 social workers/researchers.

Two hundred and eighty three street children were identified through referral sampling. This sample represented all major ethnic and religious groups. Nearly $62 \%$ were aged 14 years or less. Two hundred and ten (74\%) were boys. Around 40\% lived with one or both parents, but nearly $18 \%$ lived alone. Two thirds had never enrolled in school. Basic sociodemographic data of the sample of street children are shown in Table 1. 
Table 1: Basic socio-demographic data of the sample of street children

\begin{tabular}{|c|c|c|c|}
\hline & $\begin{array}{l}\text { Female }(n=73) \\
\text { Number }(\%)\end{array}$ & $\begin{array}{l}\text { Male }(n=210) \\
\text { Number }(\%)\end{array}$ & $\begin{array}{l}\text { Total }(n=283) \\
\text { Number }(\%)\end{array}$ \\
\hline $\begin{array}{l}\text { Age } \\
10 \text { years or less } \\
11-12 \text { years } \\
13-14 \text { years } \\
15-16 \text { years } \\
17-<18 \text { years }\end{array}$ & $\begin{array}{l}33(45.2) \\
14(19.2) \\
17(23.3) \\
05(06.8) \\
04(05.5)\end{array}$ & $\begin{array}{l}46(21.9) \\
32(15.2) \\
33(15.7) \\
58(27.6) \\
41(19.5)\end{array}$ & $\begin{array}{l}79(27.9) \\
46(16.2) \\
50(17.7) \\
63(22.3) \\
45(15.9)\end{array}$ \\
\hline $\begin{array}{l}\text { Ethnicity } \\
\text { Sinhala } \\
\text { Tamil } \\
\text { Moor } \\
\text { Other } \\
\end{array}$ & $\begin{array}{l}31(42.5) \\
23(31.5) \\
14(19.2) \\
05(06.8)\end{array}$ & $\begin{array}{l}74(35.2) \\
5626.7) \\
57(27.1) \\
23(10.9)\end{array}$ & $\begin{array}{l}105(37.1) \\
79(27.9) \\
71(25.1) \\
28(09.9)\end{array}$ \\
\hline $\begin{array}{l}\text { Religion } \\
\text { Buddhist } \\
\text { Hindu } \\
\text { Islam } \\
\text { Catholic/Christian } \\
\text { Other }\end{array}$ & $\begin{array}{l}30(41.1) \\
20(27.4) \\
18(24.7) \\
03(04.1) \\
02(02.7)\end{array}$ & $\begin{array}{l}65(30.9) \\
50(23.8) \\
71(33.8) \\
16(07.6) \\
08(03.8)\end{array}$ & $\begin{array}{l}95(33.6) \\
70(24.7) \\
89(31.4) \\
19(06.7) \\
10(03.5)\end{array}$ \\
\hline $\begin{array}{l}\text { Lives with } \\
\text { Both parents } \\
\text { Mother only } \\
\text { Father only } \\
\text { Non-parent partner of mother or father } \\
\text { Grand parent } \\
\text { Aunt / Uncle } \\
\text { Sibling/s } \\
\text { Neighbour } \\
\text { Others } \\
\text { None }\end{array}$ & $\begin{array}{l}07(09.6) \\
13(17.8) \\
08(11.0) \\
05(06.8) \\
14(19.2) \\
06(08.2) \\
12(16.4) \\
03(04.1) \\
03(04.1) \\
02(02.7)\end{array}$ & $\begin{array}{l}10(04.8) \\
57(27.1) \\
20(09.5) \\
15(07.1) \\
17(08.1) \\
11(05.2) \\
08(03.8) \\
16(07.6) \\
08(03.8) \\
48(22.8)\end{array}$ & $\begin{array}{l}17(06.0) \\
70(24.7) \\
28(09.9) \\
20(07.1) \\
31(10.9) \\
17(06.0) \\
20(07.1) \\
19(06.7) \\
11(03.9) \\
50(17.7) \\
\end{array}$ \\
\hline $\begin{array}{l}\text { Level of education } \\
\text { Never enrolled in school } \\
\text { Completed } 1-5 \text { years of schooling } \\
\text { Completed } 6-10 \text { years of schooling }\end{array}$ & $\begin{array}{l}52(71.2 \%) \\
18(24.7 \%) \\
03(04.1 \%)\end{array}$ & $\begin{array}{l}128(61.0 \%) \\
53(25.2 \%) \\
29(13.8 \%)\end{array}$ & $\begin{array}{l}180(63.6 \%) \\
71(25.1 \%) \\
32(11.3 \%)\end{array}$ \\
\hline
\end{tabular}

The themes that emerged from qualitative data analysis included the common factors associated with initiation of street life, the current lifestyle of the street children, and factors associated with their continuation of street life.
Factors associated with the initiation of street life The facilitators of initiation of street life of the sample of street children are shown in Table 2. Primary mediating factors for initiation of street life of the sample of street children are shown in Table 3.

Table 2: The facilitators of initiation of street life of the sample of street children

\begin{tabular}{|l|c|c|c|}
\hline Facilitator/s & $\begin{array}{c}\text { Female (n=73) } \\
\text { Number (\%) }\end{array}$ & $\begin{array}{c}\text { Male (n=210) } \\
\text { Number (\%) }\end{array}$ & $\begin{array}{c}\text { Total (n=283) } \\
\text { Number (\%) }\end{array}$ \\
\hline Both parents & $07(09.6 \%)$ & $33(15.7 \%)$ & $40(14.1 \%)$ \\
\hline Mother & $07(09.6 \%)$ & $24(11.4 \%)$ & $31(11.0 \%)$ \\
\hline Father & $06(08.2 \%)$ & $22(10.5 \%)$ & $28(09.9 \%)$ \\
\hline Relative & $10(13.7 \%)$ & $24(11.4 \%)$ & $34(12.0 \%)$ \\
\hline Sibling & $10(13.7 \%)$ & $10(04.8 \%)$ & $20(07.1 \%)$ \\
\hline Peer/s & $10(13.7 \%)$ & $32(15.2 \%)$ & $42(14.8 \%)$ \\
\hline Non-relative known person & $03(04.1 \%)$ & $42(19.0 \%)$ & $45(15.9 \%)$ \\
\hline Non-parent spouse of mother/father & $03(04.1 \%)$ & $05(02.4 \%)$ & $08(02.8 \%)$ \\
\hline Girl-friend / Boy-friend & $02(02.7 \%)$ & $01(0.5 \%)$ & $03(01.1 \%)$ \\
\hline Born on the street & $13(17.8 \%)$ & $12(05.7 \%)$ & $25(08.8 \%)$ \\
\hline Other & $02(02.7 \%)$ & $05(02.4 \%)$ & $07(02.5 \%)$ \\
\hline
\end{tabular}


Table 3: Primary mediating factors for initiation of street life of the sample of street children

\begin{tabular}{|l|c|c|c|}
\hline \multicolumn{1}{|c|}{ Mediating factor } & $\begin{array}{c}\text { Female (n=73) } \\
\text { Number (\%) }\end{array}$ & $\begin{array}{c}\text { Male (n=210) } \\
\text { Number (\%) }\end{array}$ & $\begin{array}{c}\text { Total (n=283) } \\
\text { Number (\%) }\end{array}$ \\
\hline Extreme poverty & $13(17.8)$ & $32(15.2)$ & $45(15.9)$ \\
\hline Born in the street & $13(17.8)$ & $12(05.7)$ & $25(08.8)$ \\
\hline Commercial sex work of mother & $08(11.0)$ & $12(05.7)$ & $20(07.1)$ \\
\hline Neglect by one or both parents & $10(13.7)$ & $13(06.2)$ & $23(08.1)$ \\
\hline Father addicted to alcohol & $10(13.7)$ & $35(16.7)$ & $45(15.9)$ \\
\hline Death of one or both parents & $05(06.8)$ & $46(22.0)$ & $51(18.0)$ \\
\hline Imprisonment of a parent & $08(11.0)$ & $12(05.7)$ & $20(07.1)$ \\
\hline Overseas migration of mother & $03(04.1)$ & $03(01.4)$ & $06(02.1)$ \\
\hline Other & $03(04.1)$ & $45(21.4)$ & $48(17.0)$ \\
\hline
\end{tabular}

\section{Current lifestyle of the street children}

Many children $(\mathrm{n}=80 ; 28.3 \%)$ help their parents /guardians in income generation while others $(\mathrm{n}=45$; $15.9 \%)$ strive to earn their own. Most children $(\mathrm{n}=158 ; 55.8 \%)$ do both. The income generating activities of these children include begging ( $\mathrm{n}=66$; $23.3 \%$ ), sale of fruits / vegetables / lunch packets / meat / fish $(\mathrm{n}=112 ; 39.6 \%)$, heavy manual labour $(\mathrm{n}=85 ; 30.0 \%)$, working as helpers in motor garages $(\mathrm{n}=20 ; 7.1 \%) /$ markets $(\mathrm{n}=36 ; 12.7 \%) /$ other smallscale industries $(\mathrm{n}=28 ; 9.9 \%)$, cleaning public toilets and buildings $(\mathrm{n}=19 ; 6.7 \%)$, and collecting recyclable papers, cardboards, metals, glass materials $(\mathrm{n}=53$; $18.7 \%)$ etc.
In addition to the above legitimate occupations, some $(n=175 ; 61.8 \%)$ also engage in various illicit activities. These include drug peddling $(\mathrm{n}=109$; $38.5 \%)$, robbery and pick-pocketing $(\mathrm{n}=69 ; 24.4 \%)$, commercial sex work $(\mathrm{n}=60 ; 21.2 \%)$ and pimping $(\mathrm{n}=49 ; 17.3 \%)$.

Although some of these activities, both legal and illegal, are carried out alone by children $(n=137$; $48.4 \%$ ), many of them engage in these as groups $(\mathrm{n}=215 ; 76.0 \%)$, which at times also show territorial behaviours.

Factors associated with continuation of street life Factors perceived to be associated with children's continuation of street life are shown in Table 4.

Table 4: Factors perceived to be associated with children's continuation of street life

\begin{tabular}{|l|c|c|c|}
\hline \multicolumn{1}{|c|}{ Perceived factors } & $\begin{array}{c}\text { Female (n=73) } \\
\text { Number (\%) }\end{array}$ & $\begin{array}{c}\text { Male (n=210) } \\
\text { Number (\%) }\end{array}$ & $\begin{array}{c}\text { Total (n=283) } \\
\text { Number (\%) }\end{array}$ \\
\hline Happy with / do not want to change current lifestyle & $20(27.4)$ & $36(17.1)$ & $56(19.8)$ \\
\hline Changing will be a mental stress & $32(43.8)$ & $58(27.6)$ & $90(31.8)$ \\
\hline Not aware of opportunities & $50(68.5)$ & $178(84.8)$ & $228(80.6)$ \\
\hline Poverty & $61(83.6)$ & $183(87.1)$ & $244(86.2)$ \\
\hline $\begin{array}{l}\text { Do not have appropriate clothes etc. to wear when } \\
\text { presenting to prospective alternative employers }\end{array}$ & $41(56.2)$ & $123(58.6)$ & $164(58.0)$ \\
\hline Low level of education & $65(89.0)$ & $184(87.6)$ & $249(88.0)$ \\
\hline Low level of / lack of occupational skills & $67(91.8)$ & $190(90.5)$ & $257(90.8)$ \\
\hline Lack of identification documents & $33(45.2)$ & $98(46.7)$ & $131(46.3)$ \\
\hline Other & $08(11.0)$ & $12(05.7)$ & $20(07.1)$ \\
\hline
\end{tabular}

\section{Discussion}

Our sample of street children was predominantly boys, which confirms findings in other parts of the world $^{10,11}$. The ethnic proportions of street children did not represent the ethnic composition of either Sri Lanka or Colombo District ${ }^{12}$, the ethnic minorities being over-represented. This is a change from previous findings ${ }^{8}$. Similarly, the Hindu and Islam religions were also over-represented among the street children compared to the national and district figures ${ }^{12}$. These observed trends in ethnic and religious composition could probably be due to the fact that the majority of the population of Colombo City has, over the previous decade, become composed of minority ethnic and religious groups and a considerable number of them live in congested urban areas ${ }^{7}$. An alarmingly high percentage $(35 \%)$ of street children live in single-parent families compared to the national figure of $15-20 \%{ }^{10}$. Considering that $42 \%$ live with non-parent guardians and $18 \%$ live alone, poor family functioning, as also 
shown in other parts of the world ${ }^{5,7,10}$, is only to be expected. Only $65 \%$ of the children maintained some contact with family (parent/sibling/relative) and this is less than what has been reported previously in Sri Lanka $^{8}$ and elsewhere ${ }^{11}$. Most children have no or poor educational achievements and thereby are similar to street children in other countries ${ }^{10,11,13}$.

The fact that $42 \%$ of children have been introduced to the street life by his/ her own family indicates that this social problem could run into generations. The significant role played by non-family contacts in bringing the children to streets further indicates the poor family functioning that existed among these children even prior to their street life. Nine percent of children have been born on the street, implying that a significant number of their families lack the minimum requirement of a shelter.

Extreme poverty has been a significant factor in forcing the children to the streets in Sri Lanka as is the case elsewhere ${ }^{7,10,11,14}$. Further, as in other countries $^{10,15,16}$, loss of one or both parents was identified as an important factor for initiation of street life but the family disintegration was lower than what has been previously reported ${ }^{8}$. Although comparatively small in number, overseas migration of mother has been stated as the primary mediating factor to initiate street life by some children. This also confirms previously reported disadvantages faced by children of migrant women ${ }^{17}$.

Interestingly, the street children are an important sector in the economy of Colombo City as they are engaged in a variety of productive occupations. This is also similar to the situation in other countries ${ }^{11,16,18}$. However, their engagement in illegal and antisocial activities has become a social menace. This is not different from most other countries where many street children engage in illegal activities ${ }^{10,19,20}$. Nevertheless, given the extent of such illegal engagements and their adverse impacts, this warrants appropriate mitigatory initiatives.

Most communities are resistant to change ${ }^{21}$, and the street children could not be different. In addition to this natural resistance, their current incomegenerating activities are closely linked with the street life, and provision of satisfactory alternatives could be the only mean of weaning them off the streets. Unfortunately, one fourth of the children were not aware of alternative opportunities. Those who did, and were courageous enough to venture out seeking alternative options, were faced with barriers such as poor educational achievements, inadequate skills, and lack of formal birth certificates and identity documents, which could be overcome if appropriate constructive and multifaceted policy and policy instruments are put in place.

\section{Conclusions}

Disadvantaged socio-economic conditions, poor family functioning and family influence have brought the children to the streets. Concerted efforts of multiple stakeholders are required to overcome the barriers which effectively prevent habilitation or rehabilitation of street children.

\section{References}

1. West A. At the margins: Street children in Asia and the Pacific: Regional and Sustainable Development Department, Asian Development Bank; 2003.

2. Guzman LS. Helping street children in especially difficult circumstances. Manila: National Association for Social Work Education and The National Joint Project for Street Children; 1992.

3. United Nations Children's Fund (UNICEF). The state of world's children: Excluded and invisible. New York: UNICEF; 2006.

4. Ennew J. Street and working children: A guide to planning - Development manual - 4. London: Save the Children; 1994.

5. Glauser B. Street children: Deconstructing a construct. Philadelphia: The Falmer Press; 1990.

6. Benítez STD. State of world's street children: violence. London: Consortium for Street Children (UK); 2007.

7. Wijewardana BVN. Deviant behaviours of street children; with special reference to Colombo Fort and Pettah. Colombo: University of Sri Jayewardenepura; 2008.

8. Senanayake MP, Ranasinghe A, Balasuriya C. Street children--a preliminary study. Ceylon Medical Journal 1998; 43(4):191-3.

9. Nada KH, Suliman EDA. Violence, abuse, alcohol and drug use, and sexual behaviours in street children of Greater Cairo and Alexandria, Egypt. AIDS 2010; 24 (Supplement 2):S39-44. http://dx.doi.org/10.1097/01.aids.0000386732.02 $\underline{425 . \mathrm{d} 1}$ 
10. Jayasekara S, Prathap K. Law and the street children. Mumbai: JP Publishers; 2009.

11. Vameghi M, Sajjadi H, Rafiey H, Rashidian A. Systematic review of studies on street children in Iran in recent decade: poverty, a risk factor for becoming a street child. Social Welfare Quarterly. 2010; 9(35):337-78.

12. Department of Census and Statistics of Sri Lanka. Census of Population and Housing 2001. Colombo: Department of Census and Statistics of Sri Lanka; 2001.

13. Anarfi JK. Vulnerability to sexually transmitted disease: street children in Accra. Health Transition Review 1997; 7:281-306.

14. Panter-Brick C. Street children, human rights, and public health: A critique and future directions. Annual Review of Anthropology 2002; 31:147-71.

http://dx.doi.org/10.1146/annurev.anthro.31.040 $\underline{402.085359}$

15. Foster G. The capacity of the extended family safety net for orphans in Africa. Psychology, Health \& Medicine 2000; 5(1):55-62. http://dx.doi.org/10.1080/135485000106007

16. Aptekar L, Heinonen P. Methodological implications of contextual diversity in research on street children. Children, Youth and Environments. 2003; 13(1).
17. Senaratna BCV. Left-behind children of migrant women: Difficulties encountered and strengths demonstrated. Sri Lanka Journal of Child Health 2012; 41(2): 71-5.

18. Agnelli S. Street children: a growing urban tragedy. UK: Weidenfeld and Nicholson Ltd; 1986.

19. Hech T. At home in the street: Street children of Northeast Brazil. UK: Cambridge University Press; 1998.

20. Bezerra KF, Gurgel RQ, Chinenye Ilozue, Castaneda DN. Estimating the number of street children and adolescents in two cities of Brazil using capture-recapture. Journal of Paediatrics and Child Health 2011; 47(8):524-9. http://dx.doi.org/10.1111/j.14401754.2011.0201 $\underline{5 . x}$

21. Dent EB, Goldberg SG. Challenging "Resistance to Change". The Journal of Applied Behavioural Science 1999; 35(1):25-41. http://dx.doi.org/10.1177/0021886399351003 